Abstracta Iranica Abstracta Iranica

Revue bibliographique pour le domaine irano-aryen

Volume 27 | 2006

Comptes rendus des publications de 2004

« Al-Māhānī's Commentary on the Concept of Ratio ». Arabic Sciences and Philosophy, 12 (2002), pp. 9-52.

Benno van Dalen

(2) OpenEdition Journals

Édition électronique

URL : http://journals.openedition.org/abstractairanica/6344

ISSN : 1961-960X

Éditeur :

CNRS (UMR 7528 Mondes iraniens et indiens), Éditions de l'IFRI

Édition imprimée

Date de publication : 15 mai 2006

ISSN : 0240-8910

Référence électronique

Benno van Dalen, « «Al-Māhānī's Commentary on the Concept of Ratio ». Arabic Sciences and Philosophy, 12 (2002), pp. 9-52. », Abstracta Iranica [En ligne], Volume 27 | 2006, document 295, mis en ligne le 02 janvier 2007, consulté le 25 septembre 2020. URL : http://journals.openedition.org/ abstractairanica/6344

Ce document a été généré automatiquement le 25 septembre 2020.

Tous droits réservés 


\title{
« Al-Māhānī's Commentary on the Concept of Ratio ». Arabic Sciences and Philosophy, 12 (2002), pp. 9-52.
}

\author{
Benno van Dalen
}

1 Abū 'Abdallāh Muḥammad ibn 'Īsā ibn Ahmmad al-Māhānī (fl. 865) was the author of one of the earliest Arabic commentaries on the treatment of ratio and proportionality in Book V of Euclid's Elements. In this commentary, extant in nine manuscripts, he provides an alternative, equivalent definition of ratio by means of anthyphairesis, a process similar to the Euclidean algorithm for finding the greatest common divisor of two numbers. In this article al-Māhānī's definition is explained and some possible reasons why Muslim mathematicians considered it "to express the essence of the sameness of ratios" and why they preferred it to Euclid's definition are given. Three appendixes contain an edition of the Arabic text with an English translation and an extensive mathematical commentary. Al-Māhānī's approach to anthyphairetic ratios has been compared to those of al-Nayrīzī and 'Umar al-Khayyām by Jan Hogendijk (cf. Abs. Ir. 25 (2002), c.r. $\left.n^{\circ} 271\right)$.

\section{INDEX}

Thèmes : 10. Histoire des Sciences et des Techniques

nompropre Khayyām, Māhāni, Nayrizi 


\section{AUTEURS}

BENNO VAN DALEN

J. W. Goethe-Universität - Frankfurt 